\title{
Comparison of bioavailability of krill oil versus fish oil and health effect
}

\author{
This article was published in the following Dove Press journal: \\ Vascular Health and Risk Management \\ 28 August 2015 \\ Number of times this article has been viewed
}

\author{
Stine M Ulven' \\ Kirsten B Holven ${ }^{2}$ \\ 'Department of Health, Nutrition \\ and Management, Faculty of Health \\ Sciences, Oslo and Akershus \\ University College of Applied \\ Sciences, ${ }^{2}$ Department of Nutrition, \\ Institute for Basic Medical Sciences, \\ University of Oslo, Oslo, Norway
}

Background: The aim of this review is to summarize the effects of krill oil (KO) or fish oil (FO) on eicosapentaenoic acid (EPA) and docosahexaenoic acid (DHA) incorporation in plasma phospholipids or membrane of red blood cells (RBCs) as shown in human and animal studies. Furthermore, we discuss the findings in relation to the possible different health effects, focusing on lipids, inflammatory markers, cardiovascular disease risk, and biological functions of these two sources of long-chain n-3 polyunsaturated fatty acids (PUFAs).

Methods: A literature search was conducted in PubMed in January 2015. In total, 113 articles were identified, but based on selection criteria, 14 original papers were included in the review.

Results: Studies on bioavailability of EPA and DHA from KO and FO in humans and animals are limited and the interpretation is difficult, as different amounts of EPA and DHA have been used, duration of intervention differs, and different study groups have been included. Two human studies - one postprandial study and one intervention study - used the same amount of EPA and DHA from KO or FO, and they both showed that the bioavailability of EPA and DHA from KO seems to be higher than that from FO. Limited effects of KO and FO on lipids and inflammatory markers in human and animal studies were reported. Gene expression data from animal studies showed that FO upregulated the cholesterol synthesis pathway, which was the opposite of the effect mediated by KO. KO also regulated far more metabolic pathways than FO, which may indicate different biological effects of $\mathrm{KO}$ and $\mathrm{FO}$.

Conclusion: There seems to be a difference in bioavailability of EPA and DHA after intake of $\mathrm{KO}$ and FO, but more studies are needed before a firm conclusion can be made. It is also necessary to document the beneficial health effects of $\mathrm{KO}$ with more human studies and to elucidate if these effects differ from those after regular fish and FO intake.

Keywords: human studies, animal studies, gene expression, cardiovascular disease, long-chain polyunsaturated fatty acids, inflammation, lipid metabolism

\section{Introduction}

Fish consumption reduces the risk of developing cardiovascular disease (CVD) and CVD mortality. ${ }^{1,2}$ Intervention trials with fish and fish oil (FO) have shown reduced total mortality and CVD risk. ${ }^{3-6}$ Fatty fish and FO are rich in long-chain n-3 polyunsaturated fatty acids (PUFAs), namely, eicosapentaenoic acid (EPA, 20:5 n-3) and docosahexaenoic acid (DHA, 22:6 n-3). One of the beneficial health effects of longchain n-3 PUFAs may be mediated by reduction in plasma triglycerides (TGs). ${ }^{7}$ The effect of long-chain n-3 PUFAs on inflammation is uncertain. ${ }^{8,9}$

The American Heart Association dietary guidelines for long-chain n-3 PUFAs and fish intake for primary prevention of coronary diseases are two servings of fatty fish
Correspondence: Stine M Ulven

Department of Health, Nutrition and Management, Faculty of Health Sciences, Oslo and Akershus University College of Applied Sciences, PO Box 4, Street Olavs plass, 0130 Oslo, Norway

Tel +47 67236348

Email stinemarie.ulven@hioa.no 
per week. ${ }^{9}$ This recommendation will provide an amount of 250-500 mg EPA + DHA per day. ${ }^{10} \mathrm{~A}$ food-based approach for achieving adequate intake of long-chain n-3 PUFAs is recommended. ${ }^{11}$ However, for individuals who do not like fish or for other reasons choose not to include fish in their diet, nutritional supplements may be a good alternative for supply of long-chain n-3 PUFAs.

Because fish is a restricted resource, there is a growing interest in exploiting alternative sources of long-chain n-3 PUFAs. Krill oil (KO) is extracted from Antarctic krill (Euphausia superba), which is a rich source of long-chain n-3 PUFAs. Krill is by far the most dominant member of the Antarctic zooplankton community in terms of biomass and, thus, attractive for commercial harvest. Persistent organic pollutants (POPs) accumulate in marine ecosystems and in the lipid reserve of organisms, and these are efficiently removed from FO through processing and purification. ${ }^{12}$ Limited data exist if the content of POPs in FO and $\mathrm{KO}$ are comparable. In a recent study, ${ }^{13}$ a comparison between the toxicological profiles of $\mathrm{KO}$ and $\mathrm{FO}$ products showed that the two $\mathrm{KO}$ products included in the study were ranked as containing intermediate levels of POP contaminants when compared overall to the FO products analyzed in the study.

Both FO and KO contain a high proportion of EPA and DHA, but in contrast to FO, KO contains a major part of these fatty acids in the form of phospholipids (PLs) (mainly phosphatidylcholine). ${ }^{14}$ In fish, the fatty acids are mainly stored as TGs, whereas in krills, 30\%-65\% of the fatty acids are incorporated into PLs. ${ }^{14}$ Whether fatty acid esterification in TGs or PLs has impact on the efficiency of absorption of the fatty acids into the blood and on serum lipid levels are issues for discussion. Because PLs comprise the structure of cell membranes, long-chain n-3 PUFAs in the form of PLs might facilitate the passage of fatty acids through the intestinal wall and increase the bioavailability of these fatty acids in $\mathrm{KO}$, compared to when they are consumed from FO. The overall fatty acid composition in $\mathrm{KO}$ resembles that of $\mathrm{FO}$, but the EPA content is higher. ${ }^{14}$ This makes the ratio between EPA and DHA different between $\mathrm{KO}$ and FO. FO often has a ratio of approximately $1: 1$, while $\mathrm{KO}$ has a ratio of $2: 1 .^{15}$ The functional similarity of EPA and DHA lies in their ability to alter cell membrane PL fatty acid composition, disrupt lipid rafts and signal transduction, and regulate gene expression, either directly by activating transcription factors such as peroxisome proliferator-activated receptors or by activating membrane-bound receptors such as the G protein-coupled receptor GPR120. ${ }^{16}$ The functional difference between EPA and DHA is in the synthesis of eicosanoids (prostaglandins, thromboxanes, and leukotrienes), whereby they compete with arachidonic acid (AA, 20:4, n-6) as a substrate for cyclooxygenase and lipoxygenase, which gives rise to different biological responses. ${ }^{17}$ Additionally, EPA gives rise to E-series resolvins and DHA gives rise to D-series resolvins and protectins, which are anti-inflammatory mediators, which may also explain the different biological responses of EPA and DHA. ${ }^{17}$

In addition to long-chain n-3 PUFAs, KO also contains the antioxidant astaxanthin, which may have a possible health effect. ${ }^{18}$ Whether these differences in EPA and DHA levels and astaxanthin can mediate the different biological functions of $\mathrm{FO}$ and $\mathrm{KO}$ remains unclear.

The aim of this review is to summarize the effects of long-chain n-3 PUFAs after intake of KO or FO on EPA and DHA incorporation in plasma PLs or membrane of red blood cells (RBCs) in humans and animals. Furthermore, we aim to discuss the findings in relation to the possible different health effects, focusing on lipids, inflammatory markers, CVD risk, and biological function of these two sources of long-chain n-3 PUFAs.

\section{Methods for selection of studies from the literature}

A literature search was conducted in PubMed in January 2015 using the following terms: "[krill oil and absorption], [krill oil and bioavailability], [krill oil and health effects], [krill oil and omega-3], and [krill oil and n-3]." In total, 113 articles were identified, but after removing duplicates and studies not including $\mathrm{KO}$ in human or animal experiments, 45 papers were screened by reading abstracts. In total, 31 studies were excluded based on the following criteria: not an original paper $(n=13)$, not using FO and KO in the same study $(n=14)$, and health effects other than lipid levels, inflammation, and endocannabinoid levels $(n=4)$. In total, 14 original papers were included in the review. Among these, seven were clinical trials and seven were animal studies. The search was limited to English literature and the search was conducted to obtain any literature published before January 2015. One of the researchers performed the literature search and both of the researchers independently extracted the data.

\section{Results Human studies}

Seven human randomized trials - five double-blind ${ }^{19-23}$ and two open-label ${ }^{15,24}$ ones - investigating the effects of $\mathrm{KO}$ compared with FO were identified (Table 1). Three of the studies $^{19,21,24}$ included healthy subjects (between 20 years 
and 50 years), two studies ${ }^{20,22}$ included healthy overweight or obese subjects (35-64 years), and two studies ${ }^{15,23}$ included healthy subjects with normal or slightly elevated lipid levels and patients with hyperlipidemia (mean age: 40-50 years). All but one study (only male in the study by Schuchardt et $\mathrm{al}^{21}$ ) included both male and female subjects.

Two of the studies provided similar amounts of FO and $\mathrm{KO}$, but different amounts of EPA and DHA. ${ }^{22,23}$ Three of the studies compared similar amounts of EPA and DHA in FO and $\mathrm{KO},{ }^{19-21}$ and two studies gave both different amounts of oil and EPA and DHA. ${ }^{15,24}$ In two of the studies, the effect of different forms (triglyceride, ethyl ester and phospholipid forms) of EPA and DHA was compared. ${ }^{21,24}$ One study ${ }^{21}$ was a postprandial study lasting up to 72 hours after intake, whereas the intervention period in the remaining studies ranged from 4 weeks to 12 weeks.

\section{Bioavailability}

Five of the seven studies reported effects of these oils on bioavailability and/or plasma fatty acid composition of EPA and DHA. ${ }^{15,19,21,22,24}$ Ramprasath et al $^{19}$ administered similar amounts of EPA and DHA (600 mg EPA and DHA) as KO or FO to 24 healthy subjects in a 4-week crossover trial. They showed that consumption of both $\mathrm{KO}$ and $\mathrm{FO}$ increased plasma EPA and DHA levels, plasma levels of total n-3 fatty acids, level of RBC EPA, and the sum of EPA and DHA concentrations in RBCs (omega-3 index) compared with control. Intake of $\mathrm{KO}$ significantly increased plasma EPA levels, the level of total n-3 PUFAs, the level of RBC EPA, and the omega-3 index to a greater degree compared with FO. The change in omega-3 index after consumption of $\mathrm{KO}$ was two-fold higher than that with FO. Maki et $\mathrm{al}^{22}$ administered the same amount of $\mathrm{KO}$ and FO, but different amounts of EPA and DHA, in a 4-week randomized controlled trial with 76 overweight and obese men and women. The subjects were given $2 \mathrm{~g} / \mathrm{d}$ of KO (216 mg/d EPA and $90 \mathrm{mg} / \mathrm{d}$ DHA), menhaden oil (MO) (212 mg/d EPA and $178 \mathrm{mg} / \mathrm{d}$ DHA), or olive oil (OO). The increase in plasma EPA and DHA concentrations were similar for the $\mathrm{KO}$ and $\mathrm{MO}$ groups and both were significantly different compared to the control group given OO. Ulven et $\mathrm{al}^{15}$ administered different doses of $\mathrm{KO}$ and FO and different amounts of EPA and DHA in a 7-week randomized trial with 113 subjects with normal or slightly elevated total blood cholesterol and/or TG levels. The subjects were given $3 \mathrm{~g} / \mathrm{d}$ of $\mathrm{KO}(\mathrm{EPA}+\mathrm{DHA}=543 \mathrm{mg})$ or $1.8 \mathrm{~g} / \mathrm{d}$ of $\mathrm{FO}(\mathrm{EPA}+\mathrm{DHA}=864 \mathrm{mg})$. A third group did not receive any supplementation. They found a significant increase in plasma EPA, DHA, and DPA (docosapentaenoic acid) levels in the subjects supplemented with both $\mathrm{KO}$ and FO compared with the controls, but there were no significant differences in the changes in any of the n-3 PUFAs between the FO and the KO groups despite the difference in n-3 dose. All these results support the hypothesis that EPA and DHA from KO have a better bioavailability compared to those from FO.

In contrast, Laidlaw et $\mathrm{al}^{24}$ administered different amounts of oil, as well as EPA and DHA from four different n-3 supplements, in a 28-day crossover trial with 35 healthy subjects. The four supplements and doses were reesterified TG (rTG) FO (EPA, 650 mg; DHA, 450 mg), ethyl ester (EE) FO (EPA, 756 mg; DHA, 228 mg), PL KO (EPA, 150 mg; DHA, $90 \mathrm{mg}$ ), and TG salmon oil (SO) (EPA, $180 \mathrm{mg}$; DHA, $220 \mathrm{mg}$ ). The increase in whole-blood n-3 fatty acids after rTG supplementation was statistically significantly greater than for the other products; moreover, the whole-blood DHA increase, EPA + DHA increase, and EPA increase was greater than the increase of the PL and TG products. When comparing the PL KO and the TG SO groups, which had similar daily intake of EPA (150 $\mathrm{mg}$ and $180 \mathrm{mg}$, respectively), the mean whole-blood EPA percentage increase was almost identical in the two groups, suggesting that the structural form of EPA does not seem to play a role on the bioavailability.

Schuchardt et $\mathrm{al}^{21}$ compared the bioavailability of identical doses of EPA + DHA $(1,680 \mathrm{mg})$ from KO to that of other chemical forms of EPA and DHA in a double-blinded crossover postprandial study lasting up to 72 hours after intake. They gave 12 healthy male subjects a single dose of FO capsules consisting either of rTG or of EE or KO capsules consisting of EPA + DHA mainly as PLs. They found that the EPA, DHA, EPA + DHA, and total n-3 fatty acid levels in plasma PLs were higher after the $\mathrm{KO}$ treatment compared to the levels after rTG and EE treatment; however, this was not statistically significant, even though a trend was observed for difference in EPA bioavailability between rTG and $\mathrm{KO}$. This may suggest that the bioavailability of EPA and DHA in plasma PLs is higher from KO compared to that from FO.

\section{Plasma lipids}

Among the seven studies, four studies reported the effect on plasma TGs and lipoproteins. ${ }^{15,19,22,23}$ In the study by Ramprasath et al, ${ }^{19}$ the total cholesterol and low-density lipoprotein (LDL) cholesterol concentrations in the plasma were increased after intake of both $\mathrm{KO}$ and $\mathrm{FO}$ compared with control, whereas serum TG and high-density lipoprotein (HDL) cholesterol concentrations did not change with any of the treatments. The response on lipoproteins did not differ between the groups in the studies by Maki et $\mathrm{al}^{22}$ and Ulven 
Table I Human studies with krill oil and fish oil

\begin{tabular}{|c|c|c|c|c|c|}
\hline Study & Study design & Intervention & Amount of n-3 PUFA & Duration & Individuals \\
\hline $\begin{array}{l}\text { Laidlaw } \\
\text { et al }(20 \mid 4)^{24}\end{array}$ & $\begin{array}{l}\text { Open-label, } \\
\text { randomized, } \\
\text { crossover study }\end{array}$ & $\begin{array}{l}\text { Four groups: } \\
\text { I) concentrated rTG FO, } \\
\text { 2) EE FO, 3) PL KO, and } \\
\text { 4) TG SO. }\end{array}$ & $\begin{array}{l}\text { Group I: EPA, } 650 \text { mg; DHA, } \\
450 \text { mg. Group 2: EPA, } 756 \text { mg; } \\
\text { DHA, } 228 \text { mg. Group 3: EPA, } \\
\text { I50 mg; DHA, } 90 \text { mg. } \\
\text { Group 4: EPA, } 180 \text { mg; DHA, } \\
220 \text { mg }\end{array}$ & $\begin{array}{l}\text { 28-day period, } \\
\text { followed by a } \\
\text { 4-week washout } \\
\text { period }\end{array}$ & $\begin{array}{l}35 \text { healthy subjects } \\
\text { (male and female) }\end{array}$ \\
\hline $\begin{array}{l}\text { Ramprasath } \\
\text { et al }(20 \mid 3)^{19}\end{array}$ & $\begin{array}{l}\text { Double-blinded, } \\
\text { randomized, } \\
\text { placebo-controlled } \\
\text { crossover trial }\end{array}$ & $\begin{array}{l}\text { Three treatment groups: } \\
\text { I) } \mathrm{KO}, 2) \mathrm{FO} \text {, and } \\
\text { 3) placebo control, CO. }\end{array}$ & $\begin{array}{l}\text { Three treatment groups } \\
\text { including KO or FO providing } \\
600 \mathrm{mg} \text { of } \mathrm{n}-3 \text { PUFAs }\end{array}$ & $\begin{array}{l}4 \text { weeks' } \\
\text { treatment, with an } \\
\text { 8-week washout } \\
\text { period }\end{array}$ & $\begin{array}{l}24 \text { healthy volunteers with } \\
\mathrm{BMI} \text { of } 23.8 \pm 3 \mathrm{~kg} / \mathrm{m}^{2}\end{array}$ \\
\hline $\begin{array}{l}\text { Ulven } \\
\text { et al }(201 \mathrm{I})^{15}\end{array}$ & $\begin{array}{l}\text { Open single-center, } \\
\text { randomized, } \\
\text { parallel-group } \\
\text { designed study }\end{array}$ & $\begin{array}{l}\text { KO: } 3.0 \mathrm{~g} / \mathrm{d}(\mathrm{n}=4 \mathrm{I}) \text {, } \\
\text { FO: } 1.8 \mathrm{~g} / \mathrm{d}(\mathrm{n}=40) \text { vs } \\
\text { no dietary intervention } \\
(\mathrm{n}=4 \mathrm{I}) .\end{array}$ & $\begin{array}{l}\text { KO: } 543 \text { mg EPA + DHA; FO: } \\
864 \text { mg EPA + DHA vs no } \\
\text { dietary intervention }\end{array}$ & 7 weeks & $\begin{array}{l}\text { I I } 3 \text { subjects with normal } \\
\text { or slightly elevated total } \\
\text { blood cholesterol and/or } \\
\text { TG levels }\end{array}$ \\
\hline $\begin{array}{l}\text { Banni } \\
\text { et al }(20 \mathrm{II})^{20}\end{array}$ & $\begin{array}{l}\text { Randomized, } \\
\text { double-blind, } \\
\text { controlled, parallel } \\
\text { clinical trial }\end{array}$ & $\begin{array}{l}2 \mathrm{~g} / \mathrm{d} \text { dose of } \mathrm{KO} \\
(n=21), M O(n=23), \text { or } \\
\text { OO }(n=19) .\end{array}$ & $\begin{array}{l}\text { KO: } 309 \mathrm{mg} / \mathrm{d} \text { of EPA/DHA } \\
\text { 2:I; MO: } 390 \mathrm{mg} / \mathrm{d} \text { of EPA/ } \\
\text { DHA I:I }\end{array}$ & 4 weeks & $\begin{array}{l}63 \text { subjects: healthy } \\
\text { overweight or obese men } \\
\text { and women, with waist } \\
\text { circumference of } \geq 102 \mathrm{~cm} \\
\text { (men) or } \geq 88 \mathrm{~cm} \text { (women) }\end{array}$ \\
\hline $\begin{array}{l}\text { Schuchardt } \\
\text { et al }(20 \mathrm{II})^{21}\end{array}$ & $\begin{array}{l}\text { Randomized, } \\
\text { double-blind } \\
\text { crossover trial }\end{array}$ & $\begin{array}{l}\text { Three EPA + DHA } \\
\text { formulations: I) FO } \\
\text { rTGs, 2) FO EEs, and } \\
\text { 3) KO (mainly PLs). }\end{array}$ & $\begin{array}{l}\text { Total EPA + DHA intake: } \\
\text { I,680 mg for all three groups. } \\
\text { Groups I and 2: EPA intake } \\
\text { I,080 mg and DHA intake } \\
672 \mathrm{mg} \text {. Group 3: EPA intake } \\
\text { I,050 mg and DHA intake } \\
630 \mathrm{mg}\end{array}$ & $\begin{array}{l}\text { Postprandial study: } \\
\text { measurements } \\
\text { recorded } 2 \text { h, } 4 \text { h, } \\
6 \text { h, } 8 \text { h, } 24 \text { h, } \\
48 \text { h, and } 72 \text { h after } \\
\text { capsule ingestion }\end{array}$ & $\begin{array}{l}\text { I } 2 \text { healthy young men } \\
\text { between } 20 \text { years and } \\
50 \text { years and with BMI } \\
\text { between } 20 \mathrm{~kg} / \mathrm{m}^{2} \text { and } \\
28 \mathrm{~kg} / \mathrm{m}^{2}\end{array}$ \\
\hline $\begin{array}{l}\text { Maki } \\
\text { et al }(2009)^{22}\end{array}$ & $\begin{array}{l}\text { Randomized, } \\
\text { double-blind } \\
\text { parallel-arm trial }\end{array}$ & $\begin{array}{l}\text { Three groups: I) } 2 \mathrm{~g} / \mathrm{d} \\
\text { of } \mathrm{KO}, 2) 2 \mathrm{~g} / \mathrm{d} \mathrm{MO} \text {, and } \\
\text { 3) } 2 \mathrm{~g} / \mathrm{d} \text { control OO. } \\
\text { Four } 500 \mathrm{mg} \text { capsules } \\
\text { per day. }\end{array}$ & $\begin{array}{l}\mathrm{KO}: 216 \mathrm{mg} / \mathrm{d} \text { EPA and } \\
90 \mathrm{mg} / \mathrm{d} \mathrm{DHA} ; \mathrm{MO}: 212 \mathrm{mg} / \mathrm{d} \\
\text { EPA and } 178 \mathrm{mg} / \mathrm{d} \mathrm{DHA}\end{array}$ & 4 weeks & $\begin{array}{l}76 \text { healthy overweight and } \\
\text { obese men and women, } \\
35-64 \text { years of age, with } \\
\text { waist circumference of } \\
\geq 102 \mathrm{~cm} \text { (men) or } \geq 88 \mathrm{~cm} \\
\text { (women) }\end{array}$ \\
\hline
\end{tabular}




\begin{tabular}{ll}
\hline Age & Fatty acid composition \\
\hline $35 \pm 14$ years & Higher increase in omega-3 \\
& fatty acids after rTG \\
& supplementation compared \\
& with the PL and TG \\
& products. The PL group \\
& intake of EPA was similar \\
& to that of the TG group, \\
& and the whole-blood EPA \\
& increase was almost identical. \\
& Both KO and FO increased \\
& plasma EPA and DHA levels, \\
& plasma levels of total n-3 \\
& PUFAs, and RBC EPA level \\
& compared with CO. \\
& KO increased plasma EPA \\
& levels, the level of total \\
& n-3 PUFA, RBC EPA level \\
& and omega-3 index more \\
& compared to FO. \\
A significant increase in & plasma EPA, DHA, and \\
DPA in KO and FO groups \\
compared with the controls. \\
NO: $38.7 \pm 11.1$ years; \\
Nontrol: & and KO groups. \\
$40.5 \pm 12.1$ years &
\end{tabular}

35-64 years of age

Lipids

Inflammation and oxidative stress

Total and LDL-C concentrations were increased following $\mathrm{KO}$ and $\mathrm{FO}$ supplementation compared with control. No change in serum TG and HDL-C concentrations with any of the treatments.

No differences in serum lipids between the study groups.

No differences in markers of oxidative stress and inflammation between the study groups

Intake of KO significantly decreased 2-AG in obese, but not in overweight, subjects. No effect of $\mathrm{MO}$ or OO treatments on 2-AG. There was no effect of $\mathrm{KO}, \mathrm{MO}$, or $\mathrm{OO}$ on arachidonoylethanolamine (AEA)

$31 \pm 5$ years

KO: $49.4 \pm 1.7$ years; MO: $49.6 \pm 1.4$ years; and placebo:

$47.4 \pm 1.6$ years
The EPA, DHA, EPA + DHA, and total n-3 PUFA levels in plasma PLs were higher after KO treatment, compared to $r T G$ and EE. The DHA, $E P A+D H A$, and total n-3 PUFA uptake from the rTG FO formulation was higher compared to the same from EE FO, and the EPA uptake was higher after EE FO treatment than after rTG FO treatment.

The increase in plasma EPA and DHA was similar for the $\mathrm{KO}$ and $\mathrm{MO}$ groups, and both were significantly different compared to the control group.
No differences in lipoprotein lipids between groups.
No differences in hsCRP and F2-isoprostanes between groups
Other health effects

Intake of rTG was most beneficial in reducing Omega-3 Serum Equivalence Score and the Omega-3 Red Blood Cell Equivalence Score as surrogate markers for cardiovascular risk.
No difference in glucose homeostasis markers between groups. Systolic blood pressure declined significantly more in the MO group than in the control group. 
Table I (Continued)

\begin{tabular}{|c|c|c|c|c|c|}
\hline Study & Study design & Intervention & Amount of n-3 PUFA & Duration & Individuals \\
\hline $\begin{array}{l}\text { Bunea } \\
\text { et al }(2004)^{23}\end{array}$ & $\begin{array}{l}\text { Double-blind, } \\
\text { randomized trial }\end{array}$ & $\begin{array}{l}\text { Four groups: Group A: } \\
\text { KO (2-3 g daily); } \\
\text { Group B: KO (I-I.5 g } \\
\text { daily); Group C: FO } \\
\text { (3 g daily); Group } \\
\text { D: placebo (3 g/d, } \\
\text { microcrystalline } \\
\text { cellulose). }\end{array}$ & $\begin{array}{l}\text { Group A: KO } 2 \mathrm{~g} / \mathrm{d} \\
\left(\mathrm{BMI}<30 \mathrm{~kg} / \mathrm{m}^{2}\right), 3 \mathrm{~g} / \mathrm{d} \\
\left(\mathrm{BMI}>30 \mathrm{~kg} / \mathrm{m}^{2}\right) . \\
\text { Group B: KO I g/d } \\
\left(\mathrm{BMI}<30 \mathrm{~kg} / \mathrm{m}^{2}\right), \mathrm{I} .5 \mathrm{~g} / \mathrm{d} \\
\left(\mathrm{BMI}>30 \mathrm{~kg} / \mathrm{m}^{2}\right) . \text { Group C: } \\
\text { FO } 3 \mathrm{~g} / \mathrm{d}(\mathrm{I} 80 \mathrm{mg} \text { EPA + I } 20 \mathrm{mg} \\
\text { DHA/g of oil). Group D: } \\
\text { placebo } 3 \mathrm{~g} / \mathrm{d}(\text { microcrystalline } \\
\text { cellulose). }\end{array}$ & 12 weeks & $\begin{array}{l}\text { I } 20 \text { patients with } \\
\text { hyperlipidemia and with } \\
\text { blood cholesterol levels } \\
\text { between } 194 \mathrm{mg} / \mathrm{dL} \text { and } \\
348 \mathrm{mg} / \mathrm{dL} \text { ( } 18-85 \text { years) }\end{array}$ \\
\hline
\end{tabular}

Abbreviations: 2-AG, 2-arachidonoylglycerol; BMI, body mass index; d, days; DHA, docosahexaenoic acid; EE, ethyl ester; EPA, eicosapentaenoic acid; F2-isoprostanes, 8-iso-prostaglandin F2a (8-iso-PGF2a); FO, fish oil; HDL-C, high-density lipoprotein cholesterol; hsCRP, high-sensitivity C-reactive protein; h, hours; KO, krill oil; LDL-C, low-density lipoprotein cholesterol; MO, menhaden oil; OO, olive oil; PL, phospholipid; PUFA, polyunsaturated fatty acid; RBC, red blood cell; rTG, reesterified triglyceride; SO, salmon oil; TG, triglyceride; CO, corn oil; DPA, docosapentaenoic acid.

et al. ${ }^{15}$ However, a significant increase in LDL cholesterol was observed within the FO group, and a significant increase in the HDL cholesterol/TG ratio was observed within the KO group in the study by Ulven et al. ${ }^{15}$

Bunea et $\mathrm{al}^{23}$ investigated the effect of intake of $\mathrm{KO}$ and FO for 3 months on blood lipids in a randomized controlled study of 120 patients with hyperlipidemia. There were four groups; two KO groups (2-3 g/d, and 1-1.5 g/d; dependent on body mass index), an FO group (3 g FO [180 mg EPA and $120 \mathrm{mg}$ DHA/g oil]), and a control group given placebo. Both total and LDL cholesterol were reduced in all groups receiving $\mathrm{KO}$ and $\mathrm{FO}$ (within-group differences); however, the $\mathrm{KO}$ groups had a greater decrease than patients receiving FO. In contrast, subjects in the placebo group showed increased mean total cholesterol and LDL cholesterol levels. HDL cholesterol increased in all patients receiving $\mathrm{KO}$ or $\mathrm{FO}$, whereas the level of HDL cholesterol was unchanged in the placebo group. $\mathrm{KO}$ taken in doses of $2 \mathrm{~g} / \mathrm{d}$ and $3 \mathrm{~g} / \mathrm{d}$ reduced the blood TGs level significantly, whereas a daily dose of $1.0 \mathrm{~g}$ and $1.5 \mathrm{~g} \mathrm{KO}, \mathrm{FO}$, and placebo resulted in a nonsignificant reduction of blood TGs level (all within-group changes). Both FO and KO performed significantly better than placebo in the regulation of TG, total cholesterol, and HDL cholesterol levels.

\section{Other cardiovascular risk markers}

Five out of seven studies investigated the effect on other cardiovascular risk markers. ${ }^{15,20,22-24}$ Laidlaw et al ${ }^{24}$ also investigated the effect of the supplements on the OmegaScore, Omega-3 Serum Equivalence Score, and the Omega-3 RBC
Equivalence Score as surrogate markers for cardiovascular risk. They found that the rTG FO supplement was the most successful in reducing risk according to these parameters, with the EE FO supplement being quite similar, and the PL KO and TG SO supplements being less successful. However, this is not surprising as the difference in scores is calculated by the difference in plasma EPA and DHA levels.

Maki et $\mathrm{al}^{22}$ investigated the effect of $\mathrm{KO}$ and $\mathrm{FO}$ responses on glucose homeostasis, high-sensitivity C-reactive protein, F2-isoprostanes, weight, and diastolic blood pressure and demonstrated that these parameters did not differ among the groups. The systolic blood pressure declined modestly in both the $\mathrm{KO}$ and MO groups, while increasing in the control group; however, only the difference between the MO and the control group was significant. Ulven et $\mathrm{l}^{15}$ observed no statistically significant differences in the serum markers of oxidative stress and inflammation between the study groups. Bunea et $\mathrm{al}^{23}$ showed that both $\mathrm{KO}$ and $\mathrm{FO}$ reduced blood glucose levels, whereas placebo treatment resulted in a nonsignificant increase (all within-group changes). The between-group comparison showed that intake of $1 \mathrm{~g}$ and $1.5 \mathrm{~g} \mathrm{KO}$ was significantly more effective than $3 \mathrm{~g}$ FO in reducing glucose levels, whereas $2 \mathrm{~g}$ and $3 \mathrm{~g} \mathrm{KO}$ led to significantly greater reduction of glucose compared to $3 \mathrm{~g}$ FO. Both FO and $\mathrm{KO}$ performed significantly better than placebo in the regulation of glucose levels.

Plasma endocannabinoids have been suggested to be involved in the regulation of the homeostasis of body com- 
Table I (Continued)

\begin{tabular}{|c|c|c|c|c|}
\hline Age & Fatty acid composition & Lipids & $\begin{array}{l}\text { Inflammation and } \\
\text { oxidative stress }\end{array}$ & Other health effects \\
\hline $5 \mathrm{I} \pm 9.46$ years & & $\begin{array}{l}\text { KO and FO reduced } \\
\text { total cholesterol. Placebo } \\
\text { increased total cholesterol. } \\
\text { Similar effects were } \\
\text { observed for LDL-C. } \\
\text { KO and FO significantly } \\
\text { increased HDL-C, whereas } \\
\text { the level of HDL-C was } \\
\text { unchanged in the placebo } \\
\text { group. KO taken as I g/d, } \\
2 \text { g/d, and } 3 \text { g/d reduced } \\
\text { TG. A nonsignificant } \\
\text { reduction of TG after a } \\
\text { daily dose of I.5 g/d KO, } \\
\text { FO, and placebo. }\end{array}$ & & $\begin{array}{l}\text { Blood glucose levels } \\
\text { were reduced by } \mathrm{KO} \\
\text { and } \mathrm{FO} \text {, whereas placebo } \\
\text { treatment resulted in a } \\
\text { nonsignificant increase of } \\
\text { blood glucose }\end{array}$ \\
\hline
\end{tabular}

position by regulating food intake and energy expenditure. In a randomized controlled trial, Banni et $\mathrm{al}^{20}$ investigated whether an intake of $2 \mathrm{~g} / \mathrm{d}$ of $\mathrm{KO}$ (309 $\mathrm{mg} / \mathrm{d}$ of EPA/DHA), MO (390 mg/d of EPA/DHA), or OO for 4 weeks could modify plasma endocannabinoids in overweight and obese subjects. Intake of $\mathrm{KO}$, but not $\mathrm{MO}$ or $\mathrm{OO}$, significantly decreased 2-arachidonoylglycerol in obese subjects, but not in overweight subjects. There was no effect of $\mathrm{KO}, \mathrm{MO}$, or $\mathrm{OO}$ on arachidonoylethanolamine in either obese or overweight subjects; thus, KO seemed more efficient than FO in reducing plasma endocannabinoid levels.

\section{Animal studies}

Seven papers investigating the effect of KO compared with FO in animal models were identified (Table 2). The main purpose of these studies was to study the effects of $\mathrm{KO}$ and FO on inflammation and/or lipid metabolism ${ }^{25-29}$ and on arthritis. ${ }^{30}$ One study ${ }^{31}$ investigated the effect of different sources of n-3 fatty acids on digestibility, tissue deposition, eicosanoid metabolism, and oxidative stability.

\section{Bioavailability}

Among the seven papers, four studies reported data on bioavailability and digestibility of EPA and DHA from $\mathrm{KO}$ and FO. ${ }^{26,27,29,31}$ In one of the studies, the same amounts of FO or $\mathrm{KO}$, but different amounts and structural forms of EPA and DHA (TG versus PL), were used in the experiments, ${ }^{29}$ while in two studies, different amounts of $\mathrm{FO}$ and $\mathrm{KO}$, but similar doses of EPA and DHA were used in the experiments. ${ }^{26,27}$
Tou et $\mathrm{al}^{31}$ examined the effects of different sources of $\mathrm{n}-3$ PUFAs.

Tillander et $\mathrm{al}^{29}$ used a high-fat diet model and fed the mice with similar doses of KO and FO for 6 weeks. The content of EPA and DHA was lower in KO compared to that in FO, but both groups showed significantly increased plasma and liver PLs of EPA and DHA compared to controls. No difference in increase of EPA and DHA was seen between the $\mathrm{FO}$ and the $\mathrm{KO}$ groups, which indicates that $\mathrm{KO}$ may have a higher bioavailability compared to FO.

Vigerust et $\mathrm{al}^{26}$ used a high-fat-diet transgenic mouse model expressing human tumor necrosis factor (TNF) and fed the mice with similar doses of EPA and DHA from KO and FO for 6 weeks. In the plasma, EPA and DHA significantly increased in both groups compared to controls. The increase in plasma EPA and DHA between the two groups did not differ, suggesting that the bioavailability is not dependent on the structural form of EPA and DHA. Batetta et $\mathrm{al}^{27} \mathrm{fed}$ Zucker rats with similar doses of EPA and DHA for 4 weeks, and they reported that plasma EPA and DHA were higher in the $\mathrm{FO}$ and $\mathrm{KO}$ groups compared to the levels in the corn oil, (CO) group. In the study by Tou et al, ${ }^{31}$ Sprague Dawley rats were fed a high-fat diet consisting of different marine oils, all containing different amounts of EPA and DHA, for 8 weeks. They measured the digestibility using the formula [(fatty acid intake - fecal fatty acids)/(fatty acid intake) $] \times 100$ and showed no significant difference in EPA digestibility among rats fed the different marine oils. The DHA digestibility was higher in SO- than KO-fed rats. There were no significant 
Table 2 Animal studies with krill oil and fish oil

\begin{tabular}{|c|c|c|c|c|c|}
\hline Study & $\begin{array}{l}\text { Animal } \\
\text { model }\end{array}$ & Amount of n-3 PUFA & Duration & Experimental diet & $\begin{array}{l}\text { Plasma lipids and plasma } \\
\text { fatty acid composition } \\
\text { (EPA and DHA) }\end{array}$ \\
\hline $\begin{array}{l}\text { Tillander } \\
\text { et al }(2014)^{29}\end{array}$ & $\begin{array}{l}\text { Male } \\
\text { C57BL/6J } \\
\text { mice }\end{array}$ & $\begin{array}{l}\text { Control: EPA } 0.03 \text { E\%, DHA } \\
0.05 \text { E\%; FO group: EPA } 8.97 \\
\text { E\%, DHA } 6.40 \text { E\%; KO: EPA } \\
5.23 \text { E\%, DHA } 2.28 \text { E\% }\end{array}$ & 6 weeks & $\begin{array}{l}\text { Mice were fed ad libitum } \\
\text { either a high-fat diet }(\mathrm{HF}) \\
\text { containing } 24 \%(\mathrm{w} / \mathrm{w}) \text { fat } \\
(21.3 \% \text { lard and } 2.3 \% \text { soy oil) } \\
\text { ( } \mathrm{n}=9), \mathrm{HF} \text { diet supplemented } \\
\text { with FO (I5.7\% lard, } 2.3 \% \text { soy } \\
\text { oil, and } 5.8 \% \text { FO) ( } \mathrm{n}=6) \text {, or } \\
\text { HF diet supplemented with } \\
\text { KO (I5.7\% lard, } 2.3 \% \text { soy oil, } \\
\text { and } 5.7 \% \mathrm{KO})(\mathrm{n}=6) \text {. }\end{array}$ & $\begin{array}{l}\text { FO significantly reduced total } \\
\mathrm{C}, \mathrm{CEs} \text {, free C, TGs, and PLs } \\
\text { compared to control. KO } \\
\text { significantly reduced NEFA } \\
\text { compared to control. No } \\
\text { significant differences between } \\
\text { FO and KO. FO and KO } \\
\text { significantly increased EPA and } \\
\text { DHA compared to control. No } \\
\text { significant differences between } \\
\text { KO and FO. }\end{array}$ \\
\hline $\begin{array}{l}\text { Vigerust } \\
\text { et al }(2013)^{26}\end{array}$ & $\begin{array}{l}\text { Male } \\
\text { transgenic } \\
\text { mice } \\
\text { expressing } \\
\text { human TNF } \alpha\end{array}$ & $\begin{array}{l}\text { Control: EPA } 0.03 \text { wt\%, DHA } \\
0.05 \text { wt\%. FO: EPA } 5.23 \text { wt\% } \\
\text { and DHA } 2.82 \text { wt\%. KO: EPA } \\
5.39 w t \% \text { and DHA } 2.36 w t \%\end{array}$ & 6 weeks & $\begin{array}{l}\text { Mice were fed ad libitum } \\
\text { either a high-fat diet (HF) } \\
\text { containing } 23.6 \%(\mathrm{w} / \mathrm{w}) \text { fat } \\
(21.3 \% \text { lard and } 2.3 \% \text { soy oil) } \\
\text { ( } \mathrm{n}=10), \mathrm{HF} \text { diet supplemented } \\
\text { with FO ( } 18.5 \% \text { lard, } 2.3 \% \text { soy } \\
\text { oil, and } 2.9 \% \text { FO) }(\mathrm{n}=8) \text {, or HF } \\
\text { diet supplemented with KO } \\
(15.6 \% \text { lard, } 2.3 \% \text { soy oil, and } \\
5.8 \% \text { KO) }(n=8) \text {. }\end{array}$ & $\begin{array}{l}\text { KO significantly reduced TGs } \\
\text { compared to control. KO } \\
\text { and FO significantly reduced } \\
\text { total C, CE, free C, HDL-C, } \\
\text { and non-HDL-C compared to } \\
\text { control. FO significantly reduced } \\
\text { LDL-C compared to control. No } \\
\text { significant difference between FO } \\
\text { and KO. KO and FO significantly } \\
\text { increased plasma EPA and } \\
\text { DHA compared to control. } \\
\text { No significant differences } \\
\text { between FO and KO. }\end{array}$ \\
\hline $\begin{array}{l}\text { Ferramosca } \\
\text { et al }(2012)^{25}\end{array}$ & $\begin{array}{l}\text { Male Wistar } \\
\text { rats }\end{array}$ & $\begin{array}{l}\text { Control: } 0 \mathrm{~g} \text { EPA and } 0 \mathrm{~g} \\
\text { DHA } / 00 \mathrm{~g} \text { diet. FO: } 0.20 \mathrm{~g} \\
\text { EPA and } 0.29 \mathrm{~g} \text { DHA } / 100 \mathrm{~g} \\
\text { diet. KO: } 0.30 \mathrm{~g} \text { EPA and } \\
0.17 \mathrm{~g} \mathrm{DHA} / 100 \mathrm{~g} \text { diet }\end{array}$ & $1-6$ weeks & $\begin{array}{l}\text { Rats were fed ad libitum a } \\
\text { standard diet, supplemented } \\
\text { with } 2.5 \% \text { olive oil (control), } \\
2.5 \% \mathrm{FO} \text {, or } 2.5 \% \mathrm{KO} \text {. }\end{array}$ & $\begin{array}{l}\text { KO and FO significantly } \\
\text { decreased TG and C compared } \\
\text { to control. KO had a more } \\
\text { pronounced effect. }\end{array}$ \\
\hline $\begin{array}{l}\text { Tou } \\
\text { et al }(201 \mathrm{I})^{31}\end{array}$ & $\begin{array}{l}\text { Female } \\
\text { Sprague } \\
\text { Dawley rats }\end{array}$ & $\begin{array}{l}\mathrm{CO} \text { and FxO: EPA and DHA } \\
\text { not detected. KO: } 13.2 \mathrm{mg} \\
\text { EPA/g diet and } 4.6 \mathrm{mg} \mathrm{DHA} / \mathrm{g} \\
\text { diet. MO: } 5.5 \mathrm{mg} \text { EPA/g diet } \\
\text { and } 2.0 \mathrm{mg} \mathrm{DHA} / \mathrm{g} \text { diet. } \\
\mathrm{SO}: 10.0 \mathrm{mg} \text { EPA/g diet and } \\
\text { I.9 mg DHA/g diet. TO: } \\
2.6 \mathrm{mg} \text { EPA/g diet and } 2.9 \mathrm{mg} \\
\mathrm{DHA} / \mathrm{g} \text { diet }\end{array}$ & 8 weeks & $\begin{array}{l}\text { Rats were fed AIN-93G } \\
\text { diet, which consisted of } \\
\text { replacing } 7 \% \text { lipids with I } 2 \% \\
\text { lipid by weight. The dietary } \\
\text { oils consisted of one of the } \\
\text { following: I) CO }(n=10) \text {, } \\
\text { 2) FxO }(n=10), 3) \text { KO }(n=10) \text {, } \\
\text { 4) MO }(n=10), 5) \text { SO }(n=10) \text {, } \\
\text { 6) TO }(n=10) \text {. }\end{array}$ & \\
\hline $\begin{array}{l}\text { Burri } \\
\text { et al }(20 I I)^{28}\end{array}$ & $\begin{array}{l}\text { Male CBA/J } \\
\text { mice }\end{array}$ & $\begin{array}{l}\text { Control: EPA and DHA } \\
0 \mathrm{~g} / 100 \mathrm{~g} \text { diet. KO: } 0.19 \mathrm{~g} \\
\text { EPA } / 100 \mathrm{~g} \text { diet and } 0.11 \mathrm{~g} \\
\mathrm{DHA} / 100 \mathrm{~g} \text { diet. FO: } \\
0.17 \mathrm{~g} \text { EPA } / 100 \mathrm{~g} \text { diet and } \\
0.11 \mathrm{~g} \text { DHA } / 100 \mathrm{~g} \text { diet }\end{array}$ & 12 weeks & $\begin{array}{l}\text { Mice were fed AIN-93M } \\
\text { diet containing } 4 \% \text { lipid from } \\
\text { soybean oil, or soybean oil } \\
\text { substituted with I.I\% FO or } \\
\text { I.5\% KO. Total n-3 PUFA } \\
\text { amount: } 0.3 \text { I } \% \text { (FO) and } \\
0.29 \%(K O) \text {. }\end{array}$ & $\begin{array}{l}\text { No significant changes in plasma } \\
\text { TG, total C, free fatty acids, PL, } \\
\text { glucose, and insulin within or } \\
\text { between any of the groups. }\end{array}$ \\
\hline
\end{tabular}




\begin{tabular}{|c|c|c|c|}
\hline $\begin{array}{l}\text { Lipids and composition } \\
\text { of fatty acids in liver } \\
\text { (EPA and DHA) }\end{array}$ & Other lipid effects & $\begin{array}{l}\text { Inflammation and } \\
\text { oxidative stress }\end{array}$ & Other effects \\
\hline $\begin{array}{l}\text { FO and KO significantly } \\
\text { increased total C compared } \\
\text { to control. FO significantly } \\
\text { increased PLs compared } \\
\text { to control. No significant } \\
\text { difference between KO and }\end{array}$ & $\begin{array}{l}\text { FO significantly reduced VLDL-C, } \\
\text { HDL-C, and VLDL-TG compared to } \\
\text { control. VLDL-C reduction by FO } \\
\text { was significantly different from that } \\
\text { by KO. }\end{array}$ & & $\begin{array}{l}\text { FO mainly increased the expression } \\
\text { of genes involved in fatty acid } \\
\text { metabolism. KO specifically } \\
\text { decreased the expression of genes } \\
\text { involved in isoprenoid/cholesterol } \\
\text { metabolism and lipid synthesis. }\end{array}$ \\
\hline
\end{tabular}

FO. FO and KO significantly

increased EPA and DHA in

PLs compared to control. No

significant differences between

$\mathrm{FO}$ and $\mathrm{KO}$.

$\mathrm{KO}$ and $\mathrm{FO}$ significantly

increased EPA and DHA

compared to control. Significant

lower DHA increase mediated

by KO compared to that by FO.
KO significantly increased the production of acylcarnitine classes compared to control. The increase was significantly different from that caused by FO.
$\mathrm{KO}$ and $\mathrm{FO}$ significantly reduced TG and $\mathrm{C}$ compared to control. KO had a more pronounced effect.
EPA significantly highest after intake of SO. KO, MO, and SO significantly increased EPA-TG compared to $\mathrm{FxO}$. $\mathrm{KO}$ and $\mathrm{FxO}$ significantly increased EPA-PL compared to MO, SO, and TO. SO and TO significantly increased DHA compared to CO. KO, MO, SO, and TO significantly increased DHA-TG and DHA-PL compared to CO. $\mathrm{MO}, \mathrm{SO}$, and TO significantly increased DHA-TG compared to KO.
In gonadal adipose tissue, EPA significantly highest after intake of KO. DHA significantly highest after intake of $\mathrm{KO}, \mathrm{MO}$, and TO compared to $\mathrm{FxO}$ intake. DHA significantly highest after intake of $\mathrm{MO}$ and TO compared to SO intake. In retroperitoneal adipose tissue, EPA significantly highest after intake of $\mathrm{KO}$. DHA significantly highest after intake of $\mathrm{KO}$ and $\mathrm{MO}$ compared to SO intake.
FO significantly increased the hepatic content of the proinflammatory cytokine ILI 7 compared to control. No differences of other cytokines between groups.
No significant differences in urinary 13, I4-dihydro-I5keto PGE2 or II-dehydro TXB2 among groups. No differences in RBC TBARS among groups. Serum TBARS and liver TAC significantly highest after intake of $\mathrm{MO}$ compared to $\mathrm{KO}$, SO, and TO intake. No significant differences in gene expression of $\mathrm{Zn} / \mathrm{Cu}$ SOD, Mn SOD, CAT, or GSH-Px among groups.
The activity, the protein level, and the expression of the transport protein for citrate across the mitochondrial inner membrane were reduced by $\mathrm{KO}$ and $\mathrm{FO}$, which was more pronounced in $\mathrm{KO}$ group. $A C C$ and FAS activity was reduced by $\mathrm{KO}$ and $\mathrm{FO}$, being the highest in $\mathrm{KO}$ group.

No significant differences in EPA digestibility among rats fed marine oils. DHA digestibility was significantly higher after intake of SO compared to KO-fed rats. No differences in DHA digestibility in rats fed $\mathrm{MO}$ or TO compared to SO- or KO-fed rats.

KO downregulated the expression of genes involved in glucose, fatty acid, and cholesterol synthesis. FO modulated fewer pathways than KO. FO did not modulate key metabolic pathways regulated by $\mathrm{KO}$. FO upregulated the cholesterol synthesis pathway. 
Table 2 (Continued)

\begin{tabular}{|c|c|c|c|c|c|}
\hline Study & $\begin{array}{l}\text { Animal } \\
\text { model }\end{array}$ & Amount of n-3 PUFA & Duration & Experimental diet & $\begin{array}{l}\text { Plasma lipids and plasma } \\
\text { fatty acid composition } \\
\text { (EPA and DHA) }\end{array}$ \\
\hline $\begin{array}{l}\text { lerna } \\
\text { et al }(20 \mid 0)^{30}\end{array}$ & $\begin{array}{l}\text { Male DBA/I } \\
\text { mice, } \\
\text { induced with } \\
\text { arthritis } \\
\text { following } \\
25 \text { days of } \\
\text { feeding }\end{array}$ & $\begin{array}{l}\text { CO: EPA and DHA } 0 \mathrm{~g} / 100 \mathrm{~g} \\
\text { diet. KO: } 0.30 \mathrm{~g} \text { EPA/ } 100 \mathrm{~g} \\
\text { diet and } 0.14 \mathrm{~g} \text { DHA/ } 100 \mathrm{~g} \\
\text { diet. FO: } 0.29 \mathrm{~g} \text { EPA/ } 100 \mathrm{~g} \\
\text { diet and } 0.18 \mathrm{~g} \text { DHA/ } 100 \mathrm{~g} \\
\text { diet. }\end{array}$ & 68 days & $\begin{array}{l}\text { Mice were fed AIN-93G diet } \\
\text { with substitution of soybean } \\
\text { oil with a blend of oils. The } \\
\text { three diets (control and diet } \\
\text { supplemented with FO or KO) } \\
\text { were similar for total fatty } \\
\text { acids, and FO and KO were } \\
\text { balanced for EPA and DHA. }\end{array}$ & \\
\hline $\begin{array}{l}\text { Batetta } \\
\text { et al }(2009)^{27}\end{array}$ & $\begin{array}{l}\text { Male Zucker } \\
\text { rats }\end{array}$ & $\begin{array}{l}\text { CO: EPA and DHA } 0 \mathrm{~g} / 100 \mathrm{~g} \\
\text { diet. KO: } 0.30 \mathrm{~g} \text { EPA/ } 100 \mathrm{~g} \\
\text { diet and } 0.14 \mathrm{~g} \text { DHA/ } 100 \mathrm{~g} \\
\text { diet. FO: } 0.29 \mathrm{~g} \text { EPA/ } 100 \mathrm{~g} \\
\text { diet and } 0.18 \mathrm{~g} \text { DHA/ } 100 \mathrm{~g} \\
\text { diet }\end{array}$ & 4 weeks & $\begin{array}{l}\text { Rats were fed AIN-93G diet } \\
\text { with substitution of soybean } \\
\text { oil with a blend of oils. The } \\
\text { three diets (control, and diet } \\
\text { supplemented with FO or KO) } \\
\text { were similar for total fatty } \\
\text { acids, and FO and KO were } \\
\text { balanced for EPA and DHA. }\end{array}$ & $\begin{array}{l}\text { KO and FO significantly reduced } \\
\text { LDL-C compared to control. } \\
\text { FO and } \mathrm{KO} \text { significantly increased } \\
\text { TG compared to control. } \\
\text { No difference in HDL-C. FO and } \\
\text { KO significantly increased EPA } \\
\text { and DHA compared to CO. }\end{array}$ \\
\hline
\end{tabular}

Abbreviations: 2-AG, 2-arachidonoylglycerol; ACC, acetyl Co-A carboxylase; ACOXI, peroxisomal acyl-CoA oxidase; AEA, N-arachidonoylethanolamine; C, cholesterol; CAT, catalase; CE, cholesterol ester; CoA, coenzyme A; CO, corn oil; CPTII, carnitine palmitoyltransferase II; DHA, docosahexaenoic acid; EPA, eicosapentaenoic acid; FAS, fatty acid synthetase; FxO, flaxseed oil; FO, fish oil; HDL, high-density lipoprotein; GSH-Px, glutathione peroxidase; IL, interleukin; ;IL-Ia, interleukin- Ialpha, KO, krill oil; LDL-C, low-density lipoprotein cholesterol; LDLR, LDL receptor; LPS, lipopolysaccharide; MAGL, monoacylglycerol lipase; MO, menhaden oil; NEFA, nonesterified fatty acid; OO, olive oil; PGE2, prostaglandin E2; PL, phospholipid; PUFA, polyunsaturated fatty acid; RBC, red blood cell; SO, salmon oil; SOD, superoxide dismutase; TAC, total antioxidant capacity; TBARS, thiobarbituric acid-reactive substances; TG, triglyceride; TNFo, tumor necrosis factor alpha; TO, tuna oil; TXB2, thromboxane B2; VAT, visceral adipose tissue; VLDL, very-low-density lipoprotein; AIN, American Institute of Nutrition rodent diet, SAT, subcutaneous adipose tissue.

differences in DHA digestibility in rats fed $\mathrm{MO}$ or tuna oil (TO) compared to SO- or KO-fed rats.

\section{Plasma lipids}

Among the seven studies, five studies reported the effects on plasma lipids. ${ }^{25-29}$

In two of the studies, ${ }^{25,29}$ the authors used the same amount of FO or $\mathrm{KO}$, containing different amounts and EPA and DHA, in the experiments. Tillander et $\mathrm{al}^{29}$ found no differences in plasma lipids between the FO and the KO groups after 6 weeks. However, within the FO group, total plasma cholesterol, cholesterol ester, free cholesterol, TGs, and PLs were significantly reduced compared to the same in controls. In contrast, Wistar rats fed the same amount of FO and $\mathrm{KO}$ for 1-6 weeks showed significantly decreased plasma TG and total cholesterol compared to controls, but these effects seemed to be more pronounced after $\mathrm{KO}$ intake compared to FO intake. ${ }^{25}$ The reason for this discrepancy may be that Tillander et $\mathrm{al}^{29}$ used mice on a high-fat diet and not lean rats, and moreover, the amount of oil differed between the two studies.

In three of the studies, similar amounts of EPA and DHA from $\mathrm{KO}$ and $\mathrm{FO}$ were used in the experiments, and the dose of EPA and DHA was similar between the experiments. ${ }^{26-28}$ Vigerust et $\mathrm{al}^{26}$ did not observe any significant difference between the effects of $\mathrm{KO}$ and FO on plasma lipids, but $\mathrm{KO}$ significantly reduced plasma TG compared to controls, suggesting that $\mathrm{KO}$ is more effective than $\mathrm{FO}$ in lowering plasma TG. However, LDL cholesterol was significantly reduced in the FO group compared to controls, thus suggesting that $\mathrm{FO}$ is more effective than $\mathrm{KO}$ in lowering plasma LDL cholesterol. Total plasma cholesterol, free cholesterol, and HDL cholesterol were however significantly reduced in both groups compared to controls, but no differences between $\mathrm{KO}$ 


\begin{tabular}{|c|c|c|c|}
\hline $\begin{array}{l}\text { Lipids and composition } \\
\text { of fatty acids in liver } \\
\text { (EPA and DHA) }\end{array}$ & Other lipid effects & $\begin{array}{l}\text { Inflammation and } \\
\text { oxidative stress }\end{array}$ & Other effects \\
\hline & & $\begin{array}{l}\text { KO increased clinical arthritis } \\
\text { more slowly compared } \\
\text { to control. Hind paw } \\
\text { thickness and histopathology } \\
\text { associated with arthritis were } \\
\text { significantly reduced by KO } \\
\text { compared to control. FO } \\
\text { significantly increased serum } \\
\text { ILI } \alpha \text { and ILI } 3 \text { compared to } \\
\text { control. }\end{array}$ & $\begin{array}{l}\text { A significantly higher weight gain by } \\
\mathrm{KO} \text { compared to control. }\end{array}$ \\
\hline $\begin{array}{l}\text { FO and KO significantly } \\
\text { reduced TG compared to } \\
\text { control. KO significantly } \\
\text { reduced TG to a greater extent } \\
\text { compared to FO. FO and KO } \\
\text { significantly increased EPA and } \\
\text { DHA compared to control. } \\
\text { EPA was significantly higher } \\
\text { in PL after FO and KO intake } \\
\text { compared to control. DHA PL } \\
\text { was significantly increased by } \\
\text { KO compared to control. }\end{array}$ & $\begin{array}{l}\text { Heart TG was significantly reduced } \\
\text { by KO compared to control. FO and } \\
\text { KO significantly increased EPA and } \\
\text { DHA in VAT and SAT TG and PL } \\
\text { compared to control. In heart, KO } \\
\text { and FO significantly increased EPA } \\
\text { and DHA in TG and PL compared } \\
\text { to control. }\end{array}$ & $\begin{array}{l}\text { No differences in } \\
\text { proinflammatory and anti- } \\
\text { inflammatory cytokines in } \\
\text { any groups. In macrophages } \\
\text { incubated with LPSs, TNF } \alpha \\
\text { secretion was significantly } \\
\text { lower after intake of FO and } \\
\text { KO compared to control. } \\
\text { No difference between FO } \\
\text { and KO. In VAT, lower level } \\
\text { of AEA induced by KO and } \\
\text { FO compared to control. } \\
2-A G \text { level lowered by KO. } \\
\text { In liver and heart, AEA } \\
\text { lowered by KO and FO, } \\
\text { more pronounced effect by } \\
\text { KO. 2-AG increased by KO. }\end{array}$ & $\begin{array}{l}\text { In VAT, MAGL activity was } \\
\text { decreased by FO and KO compared } \\
\text { to control. In heart, MAGL activity } \\
\text { significantly decreased by KO } \\
\text { compared to control. }\end{array}$ \\
\hline
\end{tabular}

and FO were observed. These data are in line with the results of Batetta et al, ${ }^{27}$ who showed that $\mathrm{KO}$ and FO significantly reduced LDL cholesterol compared to control. In contrast, Burri et al, ${ }^{28}$ who fed mice for 12 weeks with similar amounts of EPA and DHA, did not see any changes in plasma lipids in any of the groups. These conflicting results may be due to the longer period of supplementation and probably because the mice were lean and not fed a high fat diet, as was done by Batetta et $\mathrm{al}^{27}$ and Vigerust et $\mathrm{al},{ }^{26}$ respectively.

\section{Inflammation}

Vigerust et $\mathrm{al}^{26}$ did not observe any substantial difference in levels of proinflammatory cytokines between treatment groups. Batetta et $\mathrm{al}^{27}$ compared the effects of $\mathrm{KO}$ and FO on ectopic fat and inflammation in obese rats. Lipopolysaccharides significantly increased the release of TNF $\alpha$ from all three groups; however, the increase was higher in the control compared to FO- and $\mathrm{KO}$-treated groups, with no difference between these two groups. In these obese rats, $\mathrm{KO}$ also seemed to have a more pronounced inhibitory effect on the endocannabinoid system compared to FO, which is in accordance with the results of the human study by Banni et al. ${ }^{20}$

Ierna et $\mathrm{al}^{30}$ used an arthritis-induced mouse model to show that clinical arthritis score and hind paw swelling were significantly reduced in the KO group compared to controls. Mice fed the KO also had lower infiltration of inflammatory cells into the joint and synovial layer hyperplasia when compared to control. Thus, in this mouse model, KO seems to be more efficient compared to FO, in the treatment of arthritis. $\mathrm{KO}$ did not modulate the levels of serum cytokines, whereas consumption of FO increased the level of interleukin (IL)-1a and IL-13. ${ }^{30}$ Tou et $\mathrm{al}^{31}$ observed no significant effects on the Series-2 prostaglandins, thromboxane B metabolites, 
and markers of oxidative stress when rats were fed different marine oils.

\section{Biological effects}

In four studies, the aim was to understand biological effects of $\mathrm{KO}$ and $\mathrm{FO}$ by studying gene expression levels and protein activity in the liver. ${ }^{25,26,28,29}$ Ferramosca et $\mathrm{al}^{25}$ fed the same amount of FO and $\mathrm{KO}$ to rats and both oils significantly reduced the hepatic activity and expression of the mitochondrial tricarboxylate carrier. They also observed that FO and $\mathrm{KO}$ significantly reduced the activity of enzymes catalyzing de novo lipogenesis compared to the activity in controls. Tillander et $\mathrm{al}^{29}$ used quantitative polymerase chain reaction (PCR) to study changes in hepatic gene expression after $\mathrm{KO}$ and FO supplementation. FO mainly increased the expression of genes involved in fatty acid metabolism, while KO specifically decreased the expression of genes involved in isoprenoid/cholesterol and lipid synthesis.

Vigerust et $\mathrm{al}^{26}$ showed that $\mathrm{KO}$ significantly increased the mitochondrial and peroxisomal fatty acid $\beta$-oxidation, as well as the overall carnitine turnover in the liver, which can explain the TG-lowering effect of $\mathrm{KO}$ seen in this study. Thus, it seems that $\mathrm{KO}$ has a greater potential to promote lipid catabolism. By the use of quantitative PCR, Vigerust et $\mathrm{al}^{26}$ showed that both $\mathrm{KO}$ and $\mathrm{FO}$ downregulated specific hepatic target genes involved in de novo lipogenesis and genes involved in cholesterol import and synthesis compared to the control-treated groups.

Burri et $\mathrm{al}^{28}$ also fed mice with different amounts of $\mathrm{FO}$ and KO to maintain the content of EPA and DHA similar in the two groups to evaluate the efficacy of $\mathrm{KO}$ and $\mathrm{FO}$ administration on gene expression profiling in liver. Long-chain n-3 PUFAs derived from $\mathrm{KO}$ downregulated the activity of pathways involved in hepatic glucose production as well as in lipid and cholesterol synthesis. The data also suggested that $\mathrm{KO}$ increases the activity of the mitochondrial respiratory chain. Long-chain n-3 PUFAs derived from FO modulated fewer pathways, even if the content of EPA and DHA was the same as $\mathrm{KO}$, and did not modulate key metabolic pathways regulated by KO. FO also upregulated the cholesterol synthesis pathway, which was the opposite of the effect mediated by KO.

\section{Discussion}

Studies on the bioavailability of EPA and DHA from KO and FO in humans and animals are limited and their interpretation is difficult, as different amounts of EPA and DHA have been used, duration of intervention differs among the studies, and different study groups have been included. Two human studies that are included in this review - one postprandial study and one intervention study - used the same amount of EPA and DHA from KO or FO, and they both show that the bioavailability of EPA and DHA from KO seems to be higher than from that from FO. ${ }^{19,21}$ This strengthens the hypothesis that there is a difference between the bioavailability of PUFAs from KO and FO. In contrast, Laidlaw et $\mathrm{al}^{24}$ showed that similar amounts of EPA from PL KO and TG SO resulted in the same increase in whole-blood EPA, suggesting that there is no difference in bioavailability of DHA from FO and KO. The problem in comparing these studies is that one study analyzed whole-blood fatty acids, while the two other studies used plasma PLs and plasma RBCs. In future studies, the same amount of EPA and DHA from $\mathrm{KO}$ and FO should be compared in plasma PLs, RBCs, and whole blood. If possible, adipose tissue biopsies should also be taken to study whether the fatty acids from $\mathrm{KO}$ and $\mathrm{FO}$ are differently incorporated into adipose tissue, as shown in the animal study by Tou et al. ${ }^{31}$ In animals, one study $^{29}$ also indicates that KO may have a higher bioavailability compared to FO; however, another study indicates that bioavailability is not dependent on the structural form of EPA and DHA. ${ }^{26}$

The doses of $\mathrm{KO}$ and FO, type of study subjects, and duration of the studies showed very limited effects on lipids and inflammatory markers in human studies. Most of the studies did not see any effects between the groups. In one study, ${ }^{19}$ total cholesterol and LDL cholesterol increased following intake of $\mathrm{KO}$ and FO compared to controls, while Bunea et $\mathrm{al}^{23}$ showed reduction in concentration of total cholesterol and LDL cholesterol by $\mathrm{KO}$ and $\mathrm{FO}$, as well as reduction in $\mathrm{TG}$ by $\mathrm{KO}$. $\mathrm{KO}$ (at most doses) was more efficient than FO in reducing glucose and LDL cholesterol, whereas high-dose $\mathrm{KO}$ was more efficient in reducing plasma TG than FO. ${ }^{23}$

In the future, better-designed clinical studies are warranted to gain insight into the beneficial health effects of KO compared to FO. The animal studies show that there is a very small difference between $\mathrm{KO}$ and $\mathrm{FO}$ when it comes to health effects. $\mathrm{KO}$ seems to be more efficient in reducing the concentration of plasma TG, liver TG, and endocannabinoids, compared to FO, in animal studies. No adverse effects were reported.

Because $\mathrm{KO}$ and $\mathrm{FO}$ differ in their structural form, this may influence the incorporation of EPA and DHA into cells, resulting in different biological effects. $\mathrm{KO}$ also contains the antioxidant astaxanthin that protects the unsaturated bonds in the fatty acid from oxidative damage, which may influ- 
ence the biological effects of KO. The possible biological difference between FO and $\mathrm{KO}$ was studied in animal models using gene expression analysis. ${ }^{25,26,28,29}$ EPA and DHA possibly regulate the activity of transcription factors by acting as ligands for the peroxisome-proliferator-activated receptor alpha (PPAR $\alpha)$ or influence the activity of sterol regulator element-binding protein 1-c (SREBP1c). ${ }^{32,33}$ Consequently, these fatty acids have the ability to control transcription factor activity, which in turn regulates gene expression. Many of the beneficial health effects of EPA and DHA may be linked to their role of regulating expression of genes encoding proteins involved in transport, uptake, and storage of lipids, as well as enzymes involved in metabolic pathways and processes. The results from the studies included here show that FO upregulated the cholesterol synthesis pathway, which was opposite of the effect mediated by $\mathrm{KO}$. KO also regulated more metabolic pathways than FO because glucose, fatty acid, and lipid metabolism pathways were affected by KO in some studies, and the same biological response was not seen with FO. This difference in biological effect may be caused by the different structure of PLs in $\mathrm{KO}$ and TG in FO.

In humans, it is also possible to perform biological studies using peripheral blood mononuclear cells (PBMCs), which are readily available, and FO has previously been shown to be able to modulate gene expression in these cells in human trials. ${ }^{34}$ PBMC gene expression analysis in human dietary intervention studies with $\mathrm{FO}$ and $\mathrm{KO}$ can be a powerful tool to understand the underlying molecular mechanisms of the effect mediated by these oils on lipid metabolism and inflammation in humans.

\section{Conclusion}

Studies suggest that there may be a difference in the bioavailability of EPA and DHA after intake of $\mathrm{KO}$ and FO. However, more human studies designed to compare the effect of $\mathrm{KO}$ and FO are needed to conclude if the bioavailability of EPA and DHA differs between $\mathrm{KO}$ and FO. Furthermore, it is also necessary to document beneficial health effects of $\mathrm{KO}$ with high-quality human studies and to investigate whether these effects differ compared to the effects observed after regular fish and FO intake.

\section{Acknowledgments}

This work was supported by the Oslo and Akershus University College of Applied Sciences, University of Oslo, and the Throne Holst Foundation for Nutrition Research, Norway.

\section{Disclosure}

The authors report no conflicts of interest in this work.

\section{References}

1. He K, Song Y, Daviglus ML, et al. Accumulated evidence on fish consumption and coronary heart disease mortality: a meta-analysis of cohort studies. Circulation. 2004;109(22):2705-2711.

2. Hu FB, Bronner L, Willett WC, et al. Fish and omega-3 fatty acid intake and risk of coronary heart disease in women. JAMA. 2002;287(14): 1815-1821.

3. Burr ML, Fehily AM, Gilbert JF, et al. Effects of changes in fat, fish, and fibre intakes on death and myocardial reinfarction: diet and reinfarction trial (DART). Lancet. 1989;2(8666):757-761.

4. Dietary supplementation with n-3 polyunsaturated fatty acids and vitamin $\mathrm{E}$ after myocardial infarction: results of the GISSI-Prevenzione trial. Gruppo Italiano per lo Studio della Sopravvivenza nell'Infarto miocardico. Lancet. 1999;354(9177):447-455.

5. Gissi-HF Investigators; Tavazzi L, Maggioni AP, et al. Effect of n-3 polyunsaturated fatty acids in patients with chronic heart failure (the GISSI-HF trial): a randomised, double-blind, placebo-controlled trial. Lancet. 2008;372(9645):1223-1230.

6. Yokoyama M, Origasa H, Matsuzaki M, et al; Japan EPA Lipid Intervention Study (JELIS) Investigators. Effects of eicosapentaenoic acid on major coronary events in hypercholesterolaemic patients (JELIS): a randomised open-label, blinded endpoint analysis. Lancet. 2007;369(9567):1090-1098.

7. Harris WS. n-3 fatty acids and serum lipoproteins: human studies. Am J Clin Nutr. 1997;65(5 Suppl):1645S-1654S.

8. Myhrstad MC, Retterstøl K, Telle-Hansen VH, et al. Effect of marine n-3 fatty acids on circulating inflammatory markers in healthy subjects and subjects with cardiovascular risk factors. Inflamm Res. 2011;60(4):309-319.

9. American Heart Association Nutrition Committee; Lichtenstein AH, Appel LJ, et al. Diet and lifestyle recommendations revision 2006: a scientific statement from the American Heart Association Nutrition Committee. Circulation. 2006;114(1):82-96.

10. Mozaffarian D, Rimm EB. Fish intake, contaminants, and human health: evaluating the risks and the benefits. JAMA. 2006;296(15):1885-1899.

11. Kris-Etherton PM, Innis S. Position of the American Dietetic Association and Dietitians of Canada: dietary fatty acids. J Am Diet Assoc. 2007;107(12):1599-1611.

12. Haglund P, Sporring S, Wiberg K, Bjorklund E. Shape-selective extraction of PCBs and dioxins from fish and fish oil using in-cell carbon fractionation pressurized liquid extraction. Anal Chem. 2007; 79(7):2945-2951.

13. Bengtson Nash SM, Schlabach M, Nichols PD. A nutritionaltoxicological assessment of antarctic krill oil versus fish oil dietary supplements. Nutrients. 2014;6(9):3382-3402.

14. Tou JC, Jaczynski J, Chen YC. Krill for human consumption: nutritional value and potential health benefits. Nutr Rev. 2007;65(2): 63-77.

15. Ulven SM, Kirkhus B, Lamglait A, et al. Metabolic effects of krill oil are essentially similar to those of fish oil but at lower dose of EPA and DHA, in healthy volunteers. Lipids. 2011;46(1):37-46.

16. Calder PC. Marine omega-3 fatty acids and inflammatory processes: effects, mechanisms and clinical relevance. Biochim Biophys Acta. 2015;1851(4):469-484.

17. de Roos B, Mavrommatis Y, Brouwer IA. Long-chain n-3 polyunsaturated fatty acids: new insights into mechanisms relating to inflammation and coronary heart disease. Br J Pharmacol. 2009;158(2): 413-428.

18. Yoshida $\mathrm{H}$, Yanai $\mathrm{H}$, Ito $\mathrm{K}$, et al. Administration of natural astaxanthin increases serum HDL-cholesterol and adiponectin in subjects with mild hyperlipidemia. Atherosclerosis. 2010;209(2):520-523. 
19. Ramprasath VR, Eyal I, Zchut S, Jones PJ. Enhanced increase of omega-3 index in healthy individuals with response to 4-week n-3 fatty acid supplementation from krill oil versus fish oil. Lipids Health Dis. 2013;12:178.

20. Banni S, Carta G, Murru E, et al. Krill oil significantly decreases 2-arachidonoylglycerol plasma levels in obese subjects. Nutr Metab. 2011;8(1):7.

21. Schuchardt JP, Schneider I, Meyer H, Neubronner J, von Schacky C, Hahn A. Incorporation of EPA and DHA into plasma phospholipids in response to different omega-3 fatty acid formulations - a comparative bioavailability study of fish oil vs krill oil. Lipids Health Dis. 2011;10:145.

22. Maki KC, Reeves MS, Farmer M, et al. Krill oil supplementation increases plasma concentrations of eicosapentaenoic and docosahexaenoic acids in overweight and obese men and women. Nutr Res. 2009;29(9):609-615.

23. Bunea R, El Farrah K, Deutsch L. Evaluation of the effects of Neptune Krill Oil on the clinical course of hyperlipidemia. Altern Med Rev. 2004;9(4):420-428.

24. Laidlaw M, Cockerline CA, Rowe WJ. A randomized clinical trial to determine the efficacy of manufacturers' recommended doses of omega-3 fatty acids from different sources in facilitating cardiovascular disease risk reduction. Lipids Health Dis. 2014;13:99.

25. Ferramosca A, Conte L, Zara V. A krill oil supplemented diet reduces the activities of the mitochondrial tricarboxylate carrier and of the cytosolic lipogenic enzymes in rats. J Anim Physiol Anim Nutr (Berl). 2012;96(2):295-306.
26. Vigerust NF, Bjørndal B, Bohov P, Brattelid T, Svardal A, Berge RK. Krill oil versus fish oil in modulation of inflammation and lipid metabolism in mice transgenic for TNF-alpha. Eur J Nutr. 2013;52(4): 1315-1325.

27. Batetta B, Griinari M, Carta G, et al. Endocannabinoids may mediate the ability of (n-3) fatty acids to reduce ectopic fat and inflammatory mediators in obese Zucker rats. J Nutr. 2009;139(8):1495-1501.

28. Burri L, Berge K, Wibrand K, Berge RK, Barger JL. Differential effects of krill oil and fish oil on the hepatic transcriptome in mice. Front Genet. 2011;2:45.

29. Tillander V, Bjørndal B, Burri L, et al. Fish oil and krill oil supplementations differentially regulate lipid catabolic and synthetic pathways in mice. Nutr Metab. 2014;11:20.

30. Ierna M, Kerr A, Scales H, Berge K, Griinari M. Supplementation of diet with krill oil protects against experimental rheumatoid arthritis. BMC Musculoskelet Disord. 2010;11:136.

31. Tou JC, Altman SN, Gigliotti JC, Benedito VA, Cordonier EL. Different sources of omega-3 polyunsaturated fatty acids affects apparent digestibility, tissue deposition, and tissue oxidative stability in growing female rats. Lipids Health Dis. 2011;10:179.

32. Jump DB. Fatty acid regulation of gene transcription. Crit Rev Clin Lab Sci. 2004;41(1):41-78.

33. Georgiadi A, Kersten S. Mechanisms of gene regulation by fatty acids. Adv Nutr. 2012;3(2):127-134.

34. Ulven SM, Myhrstad MC, Holven KB. Marine n-3 fatty acids and gene expression in peripheral blood mononuclear cells. Curr Cardiovasc Risk Rep. 2014;8(11):412.
Vascular Health and Risk Management

\section{Publish your work in this journal}

Vascular Health and Risk Management is an international, peerreviewed journal of therapeutics and risk management, focusing on concise rapid reporting of clinical studies on the processes involved in the maintenance of vascular health; the monitoring, prevention and treatment of vascular disease and its sequelae; and the involvement of

\section{Dovepress}

metabolic disorders, particularly diabetes. This journal is indexed on PubMed Central and MedLine. The manuscript management system is completely online and includes a very quick and fair peer-review system, which is all easy to use. Visit http://www.dovepress.com/ testimonials.php to read real quotes from published authors. 